\title{
The Realization of the Organic Integration of Ideology Education in University Classroom
}

\author{
Wen-Xuan Zhao ${ }^{1,}{ }^{*}$, Liu Fang ${ }^{2}$ \\ ${ }^{1}$ School of Economics \& Management, Huaiyin Normal University, Huai'an, Jiangsu, 223001, \\ China \\ ${ }^{2}$ School of Foreign Languages, Huaiyin Normal University, Huai'an, Jiangsu 223001, China \\ mythzhao@nate.com,875992077@qq.com
}

*Corresponding Author

Keywords: University classroom, Ideology education, Integration path

\begin{abstract}
The opening of Ideology course has a certain significance for the ideology education of college students, and the strengthening of Ideology education is also the requirement of the comprehensive development of socialism with characteristics in China. This paper points out the problems existing in the integration of Ideology education by analyzing the realization path of the organic integration of Ideology education in university classroom. The combination of Ideology education and innovation and entrepreneurship education is not only the internal demand for the development of innovation and entrepreneurship education, but also the practical need for the current ideology education reform and development. Colleges and universities should play a leading role in the value of ideology education, build a carrier of practical activities, integrate the educational curriculum system, improve the collaborative education system, and promote the organic integration of ideology education and innovation and entrepreneurship education. The integration of ideology course and student work in ideology education of college students is not only the objective requirement of social environment development, but also the realistic way out of the dilemma of ideology education and the realization of comprehensive expansion effect.
\end{abstract}

\section{Introduction}

Ideology education adheres to the educational concept of "people-oriented, educating and becoming talents". It takes ideology classroom teaching as the main channel and ideology daily education as the main position. Through the organic combination of the two, it achieves the goal of all staff, all-round and whole process education [1]. The dilemma faced by the ideology education of college students urgently requires us to break the current situation that the ideology education work is divided and everyone is fighting, actively explore the integration education mechanism of mutual penetration and mutual support, and form an organic, effective and unified ideology work pattern [2]. Ideology education in colleges and universities has an important influence on the physical and mental development of college students, and it is the main position to train college 
students to establish correct values. As China's economy enters a new normal, innovation has gradually become the driving force for China's economic transformation and development [3]. Facing the demand for innovative talents in the new era, colleges and universities should actively change their thinking on talent training, organically integrate ideology education and innovation and entrepreneurship education, continuously improve the quality of talent training, and realize the connotative development of higher education [4]. Under the new situation, colleges and universities need to cultivate a team of innovative talents with firm political positions, high overall quality, and it is necessary to integrate entrepreneurial education with ideology education, and use the core socialist values to focus on internalization and externalization. Yuxing, improve the effectiveness of education, and cultivate innovative talents that meet the needs of social development and have strong capabilities [5]. As one of the main positions of Ideology education in Colleges and universities, the opening of Ideology courses is not only of great significance to improve the ideological quality of college students, but also one of the requirements of China's development and construction of socialism with Chinese characteristics [6].

\section{The Necessity of Integration}

\subsection{Educational Philosophy}

As the premise of educational work, the old single educational idea has gradually fallen behind the development requirements of the times. At present, most ideology educators' educational ideas can't keep up with the requirements of the times, and there are also deviations in practical work [7]. Ideology education, which should be regarded as one of the important links of all-round education, is now regarded as an independent cadre training link by most educators, but it does not really understand the true significance of ideology education for college students [8]. The two important ways of ideology education in colleges and universities are classroom teaching and daily education. The goals of the two are the same and their functions are complementary, which help to improve the effectiveness of education and achieve the goals of moral education. At present, the management model of ideology education in most colleges and universities is directly led by the school party committee, with administrative assistance, and is specifically responsible for the overall responsibility of the student work department. The school party committee propaganda department, organization department, and ideology theory department closely cooperate to jointly develop college students Ideology education work, see Figure 1.

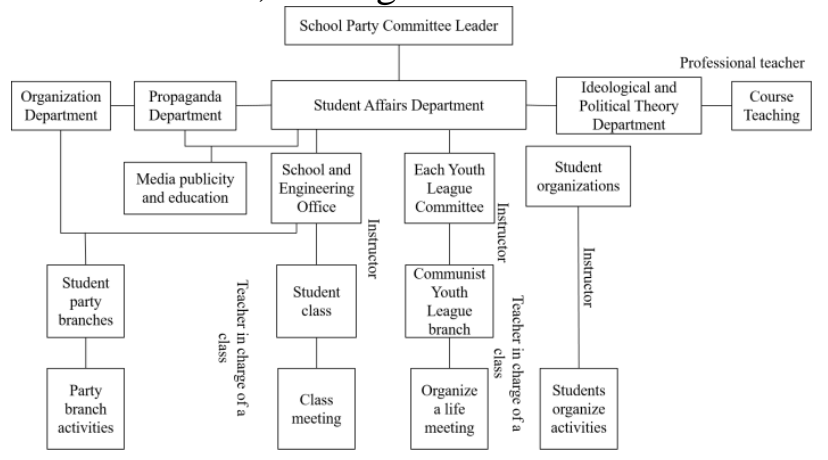

Fig.1 Management Mode of Ideology Education in Colleges and Universities

From the perspective of student work field and working group, due to long-time contact with students, student staff often have a more comprehensive and profound understanding of College Students' ideological characteristics, psychological needs and rules of psychological activities, and have a close relationship with the educational object in the process of work. In addition, the 
convenience of contact with students and the diversification of educational approaches are also important, So as to create favorable conditions for them to carry out ideology education.

\subsection{Problems Faced by Integration}

Colleges and universities should integrate ideology education into entrepreneurship education, take socialist core values as ideological guidance, promote entrepreneurship awareness with Marxist theory, stimulate entrepreneurial enthusiasm with ideal and belief education, restrain entrepreneurial behavior with moral laws and regulations, guide entrepreneurial psychology with mental health education, and strive to cultivate compound talents with lofty ideals, strong character, optimistic attitude, strong team consciousness and excellent quality, which is the basic criterion of adhering to the morality of higher education. In order to ensure that ideology education is effectively understood in the actual implementation process, it is necessary to build a good integration and communication platform between the student work team and ideology courses to promote communication and mutual assistance. In order to strengthen the integration of ideology courses and student work in the ideology education of college students, in addition to implementing advanced concepts and building a platform for integration, it is also necessary to improve the ideology education system and strengthen the system's binding force [10]. A strong system can guarantee the integration of Ideology course and student work. In order to carry out the fundamental task of "establishing morality and cultivating talents", colleges and universities must adhere to the guidance of Marxism, comprehensively implement the party's educational policy, constantly strengthen ideological guidance, and implement the dominant position of Ideology education in college education and teaching.

\section{Integration Development Path of Ideology Education in Colleges and Universities}

\subsection{Implementation of Convergence}

Colleges and universities should carry out ideology education throughout innovation and entrepreneurship education, and establish the leading position of ideology education in innovation and entrepreneurship education. In order to realize the scientific, organic and effective integration of student work and ideology course in ideology education of college students, we must attach importance to the theoretical research of integration, and provide theoretical support for the integration of the two. The organic and effective integration of college student work and ideology courses is not only a practical problem, but also an important theoretical topic, which requires in-depth theoretical exploration of related issues. The formation of college students' outlook on life, values, and world outlook is a continuous and constantly changing process, generally following the law of "cognition, identification, practice, internalization, and practice". The content dissemination of Ideology education in Colleges and universities should also be in the process of innovation, enrich the content of education through data resources, and give full play to the value of education and the role of platform. 


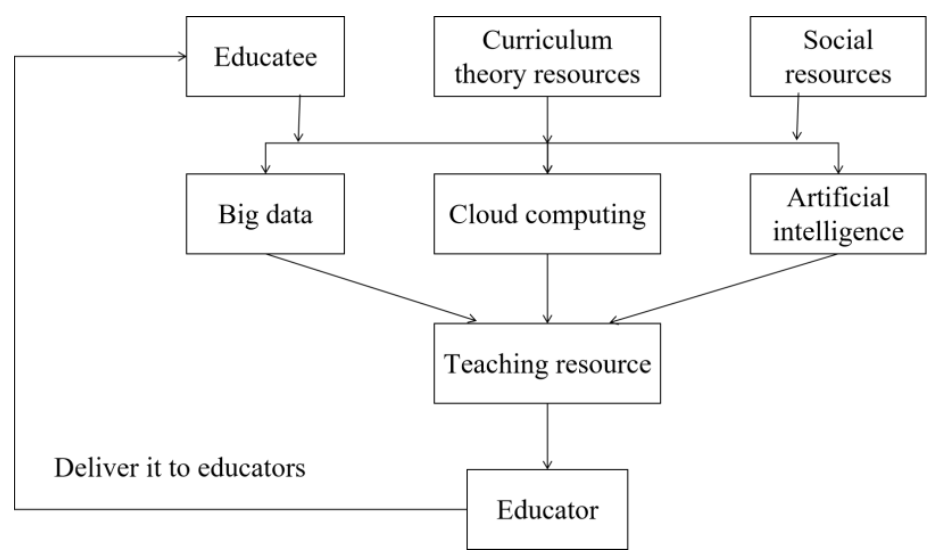

Fig.2 The Construction Path of the University's Ideology Education Resource Database

College students need to learn all kinds of theoretical knowledge and Marxist viewpoints and methods in the classroom, and then use them as action guides to solve all kinds of problems in daily life, deepen theoretical cognition and recognition in practice, and internalize them into their own code of conduct and living habits. Only internalizing them in the heart and externalizing them in the line can achieve good ideology education results. The effective integration of ideology education with students' work will make it possible to transform the traditional thesis investigation mode into quantitative assessment of work, and more intuitively reflect the final results of ideology education.

\subsection{Development Path}

In the implementation of education, schools should focus on integrating educational resources, and coordinate with universities, enterprises, and university student science parks and other educational resources to establish a curriculum practice platform. By inviting alumni and successful entrepreneurs to give lectures on learning topics, relying on college student science parks and scientific research training platforms to simulate practical projects, and the school league committee to organize entrepreneurial competitions to help students transform theoretical knowledge into practical capabilities. At the same time, the establishment of a comprehensive curriculum supervision system, from the main body of teachers, students, teaching process and other aspects of supervision, feedback results, so that colleges and universities can understand the whole process of education implementation, and timely improve according to the feedback problems, suit the remedy to the case. Colleges and universities should integrate teaching system and teaching resources, carry out teaching reform in combination with their own reality, promote the organic integration of Ideology education curriculum, innovation and entrepreneurship curriculum and professional curriculum, and realize the goal of whole curriculum education. As a worker of ideology theory, in actual education and teaching activities, we should deeply understand and study the educational objects, be good at using fresh experiences and materials, actively explore various carriers and methods that are conducive to carrying out ideology education for college students, enhance the effectiveness of education and teaching, and avoid boring theoretical preaching. In a word, through the exchange and study of the two, we can learn from each other's strengths and complement each other, and cooperate and support each other in practical work to form an educational synergy.

\section{Conclusions}

Ideology education occupies a dominant position in the cultivation of talents in colleges and universities. Innovation and entrepreneurship education is an inherent requirement for my country 
to build an innovative country and improve the quality of teaching in colleges and universities. Only when the two are integrated and developed can the quality of talent cultivation be continuously improved. Therefore, colleges and universities should play a leading role in the value of ideology education, build a carrier for practical activities, integrate the education curriculum system, improve the collaborative education system, and promote the organic integration of ideology education and innovation and entrepreneurship education. In a word, the integration of entrepreneurship education and ideology education is of great practical significance. The collaborative integration of entrepreneurship education and ideology education in Colleges and universities is not only the basis of shaping the complete personality of college students, but also the need to enhance their social adaptability. To sum up, ideology education plays a vital role in college education. As one of the carriers of Ideology education, the opening of Ideology course needs to keep up with the development trend of the times, actively seek the integration with student work, and help college students comprehensively improve their own quality under the dual norms of college education and practical work. The effective combination of college students' ideology courses and student work has become an educational model of great practical significance, which not only plays an indispensable role in the development of ideology education, but also plays a good reference role in comprehensive education. Only by further innovating education and work concepts, strengthening system construction, strengthening theoretical research, and learning and supporting each other in practical work can we truly realize the organic and effective integration of ideology courses and student work in ideology education for college students. Incorporate the concepts and content of core values to guide and educate college students to establish a correct outlook on talents, careers, employment, and life, so that they can truly feel the strength and care of the country, patriotism and gratitude spontaneously, To achieve the goal of ideology education by means of spring breeze and rain, moisturizing things silently.

\section{References}

[1] Sun Guilin. New Exploration on the path of University Education -- organic combination of cultural self-confidence and ideological and Political Education [J]. Education modernization, 2016 (19): 225-228

[2] Liu Hongwei, Yin Shengjun, Li Yue. Path exploration of Integrating Ideology education into college students' innovation and entrepreneurship basic course [J]. Journal of higher education, 2020, 000 (005): 33-36

[3] Sun Pengyi. Research on the organic integration of network hot spots and ideology education in Colleges and universities [J]. Journal of Jilin University of agricultural science and technology, 2020, 029 (002): 86-89

[4] Tan Lu. Research on the organic integration of craftsmanship cultivation and ideology education in Colleges and universities [J]. Journal of Dali University, 2018, 003 (007): 70-73

[5] Ban Ruijun, Zuo qianya, Yuan Xiaoqiang. Methods of organic integration of Ideology education and professional education in Colleges and universities [J]. Education modernization, 2019, 6 (21): 163-165

[6] Zhang Chengfeng, Fang Jianbin. Analysis on the path of Ideology education of agricultural college students from the perspective of "Rural Revitalization" strategy -- Based on the investigation of Ideology education of students in Northwest A \&amp; F University [J]. China forestry education, 2020, v.38 (03): 31-36

[7] Hu Shuji. Organic integration path of Ideology education and innovation and entrepreneurship education of college students [J]. Think tank era, 2020, 000 (007): p.194-195

[8] Chen Dongfang. Analysis on the organic integration path of excellent traditional culture and ideological and Political Education [J]. Education review, 2018, No. 228 (06): 106-109

[9] Zhang Qianqian. Research on the organic integration of College Students' innovation and entrepreneurship education and ideology education in the new media era [J]. Reporter observation (first half), 2019, 000 (024): 50-51

[10] Han Xiaofang. Idea, method and path: new exploration of Ideology education in Colleges and universities in the new era [J]. Research on Ideology course, 2019, 000 (006): 53-60 